\title{
Effect of Organic Manure and Potting Media on Germination and Early Growth of Eucalyptus torelliana F. Muell
}

\author{
Rotowa Odunayo James ${ }^{1}$, Adeagbo Ayobami Akorede ${ }^{2, ~ *, ~ A d e g o k e ~ I d o w u ~ A b i m b o l a ~}{ }^{3}$, \\ Omoake Paul Omoh ${ }^{1}$ \\ ${ }^{1}$ Department of Forestry and Wildlife Management, Nasarawa State University Keffi, Shabu Lafia, Nigeria \\ ${ }^{2}$ Department of Forest Production and Products, University of Ibadan, Ibadan, Nigeria \\ ${ }^{3}$ Department of Forestry and Wildlife Management, Federal University Gashua, Gashua, Nigeria
}

Email address:

aydeagbo@yahoo.com (A. A. Akorede)

${ }^{*}$ Corresponding author

\section{To cite this article:}

Rotowa Odunayo James, Adeagbo Ayobami Akorede, Adegoke Idowu Abimbola, Omoake Paul Omoh. Effect of Organic Manure and Potting Media on Germination and Early Growth of Eucalyptus torelliana F. Muell. American Journal of Agriculture and Forestry.

Vol. 8, No. 4, 2020, pp. 100-107. doi: 10.11648/j.ajaf.20200804.12

Received: February 17, 2020; Accepted: March 11, 2020; Published: June 28, 2020

\begin{abstract}
A field experiment was carried out to determine the growth response of Eucalyptus torelliana F. Muell. to organic manure and potting media. The experiment was conducted within the Nursery site of the Department of Forestry and Wildlife Management Nasarawa State University Lafia. Sampled seedlings were systematically numbered and tagged for easy identification and enumeration, the experiment was laid out in a $4 \times 2 \times 5$ factorial experiment in a randomized completely block design (RCBD). Analysis of variance was used to show the comparative performance of each the treatment and Duncan multiple range test (DMRT) to locate where the significant differences occur among the means. The plant variables assessed are; collar girth, plant height, number of leaves, leaf length, leaf width and leaf area. The result of growth with respect to treatment revealed that poultry dropping performed better with mean value of $31.26 \pm 8.78$ in plant height, $2.02 \pm 0.99$ in collar girth, $10.42 \pm 2.38$ leaf count, $7.04 \pm 0.91$, in leaf length $4.26 \pm 0.88$ in leaf width and $30.68 \pm 9.30$ for leaf area. It was further revelled that big size polythene pot (16 by $10 \mathrm{~cm}$ ) with mean value (plant height $29.86 \pm 9.51$, collar girth $2.05 \pm 1.14$, leaf count $10.26 \pm 2.82$, leaf length $7.25 \pm 1.32$, leaf width $4.56 \pm 0.92$ and leaf area $33.99 \pm 11.36$ ) recorded the highest and best germination. It is recommended that big size pot and poultry droppings should be adopted in raising Eucalyptus torelliana F. Muell.
\end{abstract}

Keywords: Eucalyptus torelliana F. Muell, Collar Girth, Potting Media, Leaf Count and Plant Height

\section{Introduction}

Eucalyptus torelliana F. Muell. belong to the family Myrtaceae. It is a large genus of aromatic trees far known to be indigenous to Australia, Tasmania and the neighbouring islands but today can be found growing in subtropical regions of the world [1]. It is a tall evergreen and a dense shade plant with an irregular crown, a very hard tree with smooth, tight and grey-green bark with persistent scaly, sub-fibrous base and tessellated. The leaves has a simple, leathery, variable but usually ovate, wavy margin, green above or with a pink tint, generally pubescent when young and with a wider leaf than other Eucalyptus [2]. It possesses attractive flowers with large creamy white clusters and numerous with valves well below rim of the fruit. Stamens, the creamy fruit is large and ovoid shape and with valves well below rim of the fruit. Ecalyptus has over 800 species and it is the second most widely planted multipurpose woody tree species in the world occurring under a wide range of environmental conditions [3, 4]. The remarkable adaptability of Eucalypts coupled with their fast growth and superior wood properties has driven their rapid adoption for plantation forestry in more than 100 countries [4]. There are several Eucalyptus tree improvement programs, but Eucalyptus domestication can still be considered as being at an early stage. Their general 
importance are described as short rotation hardwoods for a variety of products and ornamentals with specific emphasis on existing and emerging markets as energy products [5].

Eucalyptus plants are frequently useful in food preservation, in pharmaceuticals, physiotherapies, as pesticides, as temporary relief to minor aches and pains [1, 6]. Researches from Nigeria, Mali, Australia and CongoBrazzaville have reported that the essential oils of $E$. torelliana are rich in hydrocarbon monoterpenol, spatulenol and-pinenes, ocimene, aromadendrene and caryophyllene oxide as its characteristic constituents [7]. Essential oils from leaves and seed of the plant were reported to have possessed antibacterial activities against enteric pathogens [8], antiviral, anti-inflammatory, anti-oxidant antifungal antimicrobial antibiotic and anti-carcinogenic properties. Analyses of the seed essential oils extracts resulted in the identification of 70 compounds representing $98 \%$ of the oil [6]. In Nigeria, $E$. torelliana is used to treat gastrointestinal disorders; decoction of the leaves is used for sore throat remedy and other bacterial infections of respiratory and urinary tract. The poultice of the leaves is applied over wounds and ulcers. It decreases gastric acid production and used for the treatment of gastric and duodenal ulcers, cough associated with most pulmonary diseases. The essential oil of the leaves have been used in treatment of lung diseases, and were stated to have anti-inflammatory and remedies cancer-related symptoms, and intestinal disorders $[2,7,9]$.

E. torelliana, is one of the most important tropical tree species, with varying uses and great economic values. In view of the potential of this specie, the rate at which the tree species is being felled for commercial and other purpose is high whereas the regeneration and afforestation of the tree species is low or does not exist. This therefore give rise to the need to find a suitable solution to this problem by devising means of multiplying this specie on a large scale.

\section{Materials and Method}

\subsection{Study Area and Materials}

This experiment was carried out in Nasarawa State University, Faculty of Agriculture Lafia, located between longitude $08^{0} 35^{\prime} \mathrm{N}$ and latitude $08^{0} 33^{\prime} \mathrm{E}$, in the Guinea Savannah zone of North Central Nigeria at an altitude of about $177 \mathrm{~m}$ above the sea level. The mean monthly maximum temperature range is between $35.06^{\circ} \mathrm{C}$ to $36.40^{\circ} \mathrm{C}$ and $20.16^{\circ} \mathrm{C}$ to $20.50^{\circ} \mathrm{C}$ respectively [10]. The material and equipment used in carrying out the experiment are polythene pots, Hand trowel, wheel barrow, cutlass, spade, weighing balance, head pan, watering can, tags, meter rule, knife, hoes, veneer calliper, sack bags, marking pen and field note book.

\subsection{Site Preparation and Sowing Media}

A portion of land allocated for the experiment was cleared manually and the site was fenced with a rope. The polythene pots were perforated at the base in order to allow drainage of water. Top soil was collected from the Faculty of Agriculture,
Nasarawa state University teaching and research farm after which the polythene pots were filled with the mixed soil. (Two full head pan of organic manure i.e. poultry droppings, cow dung and one full head pan each for poultry dropping + cow dung mixed with four head pan of top soil which is ratio 2:4)

\subsection{Seed Collection, Processing and Sowing}

The seeds of E. torelliana were handpicked from a plus trees within the premises of College of Agriculture, Lafia, Nasarawa State. The seeds was manually extracted from the seeds pods after sun drying for two days. The seeds were sown first on germination bed, and then transplanted into polythene pots (one seedling per pot) at $4 \mathrm{~cm}$ depth.

\subsection{Silvicultural Operation and Treatment Combination}

Watering was carried out morning and evening for two (2) days before seeds was sown. Watering of seeds was done continuously even after sowing for another two (2) weeks after which the watering was done only in the morning. Manual weeding was carried out in other to reduce competition between weeds and Eucalyptus seedlings for water, sunlight and nutrient, and also to prevent pest infestation.

For each polythene pot size, a total of 60 seedlings were transplanted for each treatment which are: cow dung + poultry droppings, cow dung, poultry droppings and control as treatment $T_{1}, T_{2}, T_{3}$ and $T_{4}$ respectively.

\subsection{Experimental Design}

The study was laid out in a $4 \times 2 \times 5$ factorial experiment in a Randomized Completely Block Design (RCBD). The experiment had four different treatments (cow dung + poultry droppings, cow dung, poultry droppings and control) with two pots sizes (large and small pot sizes 16 by 10 and 12 by $8 \mathrm{~cm}$ respectively). Each treatment consist of twenty-four (24) experimental pots, replicated five times per treatment given a total of 120 seedlings per treatment (Figures 1 and 2).

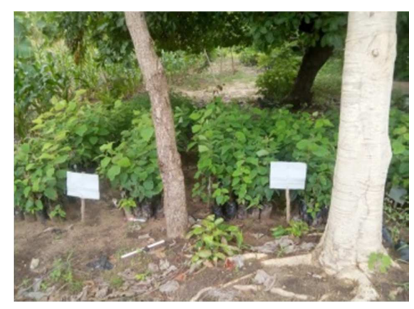

Figure 1. Experimental layout.

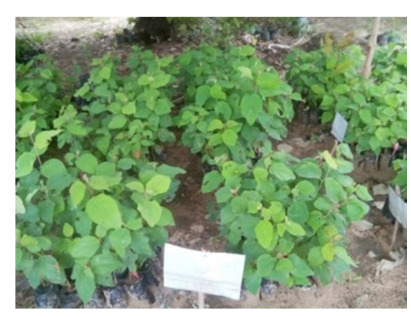

Figure 2. Experimental tagging. 


\subsection{Parameter Assessed and Data Collection}

Ten seedlings were randomly selected from each treatment and the following variables were determined: Plant height, collar girth, number of leaves, leaf length and leaf width. Plant height was measured from the collar region to the top of the seedlings by using metre rule, collar diameter was measured using veneer calliper, number of leaves were determine by manually counting the number of leaves on the seedlings and leaf length and leaf width were measured using metre rule.

\subsection{Germination Assessment and Data Analysis}

The germination rate of each test was examined to determine the best treatment for the germination of $E$. torelliana between $\mathrm{T}_{1}, \mathrm{~T}_{2}, \mathrm{~T}_{3}$ and $\mathrm{T}_{4}$ respectively. Below is the formula for calculating seeds germination percentage.

$$
\% \text { Germination }=\frac{\text { Number of germination }}{\text { Number of seed sown }} \times 100
$$

Data collected on growth variables were subjected to mean and analysis of variance (ANOVA) to show the comparative performance between the treatments. Data was analysed with respect to two organic manure applications with control and two polythene pot sizes. Analysis of variance was performed on the data to show the comparative performance of each treatment with another. Duncan Multiples Range Test (DMRT) was applied to locate significant difference among the treatment, pot size and selected variables.

\section{Result}

\subsection{Mean and Duncan Separation Value for Growth Variables on Basis of Treatment}

The result of mean values of parameter assessed on the basis of pot size used, soil treatment given and the age performance (weeks) of E. torelliana is shown in Table 1. The highest mean value of plant height $(29.86 \pm 9.51 \mathrm{~cm})$ was recorded in big pot size while the least was recorded in the small pot size $(28.32 \pm 8.38 \mathrm{~cm})$. The same was the result in girth measurement $(2.05 \pm 1.14 \mathrm{~cm}$ and $1.69 \pm 0.86 \mathrm{~cm})$, leave length, $(7.25 \pm 1.32 \mathrm{~cm}$ and $6.96 \pm 1.16 \mathrm{~cm})$, leave width $(4.56 \pm 0.92 \mathrm{~cm}$ and $4.47 \pm 1.21 \mathrm{~cm})$ and leave area $\left(33.99 \pm 11.36 \mathrm{~m}^{2}\right.$ and $\left.32.07 \pm 12.88 \mathrm{~m}^{2}\right)$ respectively. Meanwhile, small pot recorded a higher mean value of leave production with mean value of $10.28 \pm 2.40$ while big pot size had 10.26 \pm 2.82 (Table 1).

The result of treatment application shows that E. torelliana seedlings treated with poultry dropping recorded the highest mean plant height of $31.26 \pm 8.78 \mathrm{~cm}$ followed by the treatment 3 which is the combination of poultry dropping and cow dung with $30.35 \pm 9.79 \mathrm{~cm}$ the least plant height was recorded in untreated soil (control) with mean value of $24.66 \pm 6.62 \mathrm{~cm}$. The result of treatment application shows that the seedlings treated with the combination of poultry dropping and cow dung recorded the highest mean girth value of $2.18 \pm 1.31 \mathrm{~cm}$ followed by treatment 2 (which is poultry dropping) with mean value of $2.02 \pm 0.99 \mathrm{~m}$, while control again had the least mean collar girth of $2.48+1.88 \mathrm{~cm}$. The result of number of leave production shows that the seeds treated with cow dung recorded the highest mean number of leaves $(10.51 \pm 2.57)$, followed by the treatment with poultry droppings with mean value of $10.42 \pm 2.38$, while treatment 3 recorded the least number of leaves with $9.69 \pm 2.85$ (Table 1). $\mathrm{m}^{2}$

Furthermore, the result of the leave width shows that seeds treated with poultry dropping recorded the highest mean leaves width $(4.82 \pm 1.29 \mathrm{~cm})$, followed by the treatment with poultry droppings mixed with mean cow dung with mean value of $4.74 \pm 1.07 \mathrm{~cm}$, while the control treatment recorded the least leaves width of $4.21 \pm 0.88$. However, the result of leave area revels that treatment 3 (poultry droppings mixed with mean cow dung) recorded the highest mean leaves area of $37.02 \pm 12.64 \mathrm{~m}^{2}$, closely followed by the treatment 1 (Poultry droppings) leave area of $36.24 \pm 13.19 \mathrm{~m}^{2}$. The least mean leave area was recorded in the control treatment with $28.17 \pm 10.96 \mathrm{~m}^{2}$ (Table 1).

The result of age assessment of Eucalyptus torelliana within 1 to 9 week shows that there was continuous increase in the growth of Eucalyptus torelliana as week increases. Week 9 recorded the highest mean plant height $(37.91 \pm 7.04 \mathrm{~cm})$, collar girth $(2.75 \pm 1.20 \mathrm{~cm})$ leave number with mean value of $9.52 \pm 2.42$, Leave Length $7.60 \pm 1.88$, Leave width $4.96 \pm 0.84$ and leave area $38.44 \pm 11.20 \mathrm{~cm}$. Week 6 took after week 9 with mean value of $32.93 \pm 5.63 \mathrm{~cm}$ for plant height, $2.10 \pm 0.08 \mathrm{~cm}$ for collar girth $10.68 \pm 2.76$ for number of leaves, $7.33 \pm 1.16 \mathrm{~cm}$ for Leave Length $4.73 \pm 0.84 \mathrm{~cm}$ for Leave width and $35.42 \pm 10.56 \mathrm{~m}^{2}$ for leave area. The trend continued down the week as week 1 took after week 3 with mean value of $19.80+4.69 \mathrm{~cm}$ as the least plant height, week 1 again had the least mean value of collar girth $(1.04 \pm 0.38)$. The trend was again repeated in number of leaves as week 1 again had the least number of leave production with $9.55 \pm 2.15,6.45 \pm 1.14$ for Leave Length, $3.89 \pm 0.94 \mathrm{~cm}$ for Leave width and $25.91 \pm 9.52 \mathrm{~m}^{2}$ for leave area (Table 1).

Table 1. Means and Duncan's Multiple Range mean separation value of parameter assessed on the basis of Pot size, treatments and weeks.

\begin{tabular}{|c|c|c|c|c|c|c|}
\hline Source of Variation & Plant Height (cm) & Girth (cm) & Leave Num. (cm) & Leave Length $(\mathrm{cm})$ & Leave Width (cm) & Leave Area $\left(\mathrm{m}^{2}\right)$ \\
\hline \multicolumn{7}{|l|}{ Pot size } \\
\hline Big & $29.86 \pm 9.51$ & $2.05 \pm 1.14$ & $10.26 \pm 2.82$ & $7.25 \pm 1.32$ & $4.56 \pm 0.92$ & $33.99 \pm 11.36$ \\
\hline Small & $28.32 \pm 8.38$ & $1.69 \pm 0.86$ & $10.28 \pm 2.40$ & $6.96 \pm 1.16$ & $4.47 \pm 1.21$ & $32.07 \pm 12.88$ \\
\hline \multicolumn{7}{|l|}{ Treatments } \\
\hline Cow dung & $30.09 \pm 9.01 \mathrm{~b}$ & $1.95 \pm 0.88 \mathrm{~b}$ & $10.51 \pm 2.57 \mathrm{~b}$ & $7.35 \pm 1.02 \mathrm{c}$ & $4.82 \pm 1.29 b$ & $36.24 \pm 13.19 b$ \\
\hline Poultry Dropping & $31.26 \pm 8.78 b$ & $2.02 \pm 0.99 b c$ & $10.42 \pm 2.38 \mathrm{ab}$ & $7.04 \pm 0.91 b$ & $4.26 \pm 0.88 \mathrm{a}$ & $30.68 \pm 9.30 \mathrm{a}$ \\
\hline
\end{tabular}




\begin{tabular}{lllllll}
\hline Source of Variation & Plant Height $(\mathbf{c m})$ & Girth $(\mathbf{c m})$ & Leave Num. $(\mathbf{c m})$ & Leave Length $(\mathbf{c m})$ & Leave Width $(\mathbf{c m})$ & Leave Area $\left(\mathbf{m}^{2}\right)$ \\
\hline Cow Dung * Poultry & $30.35 \pm 9.79 \mathrm{~b}$ & $2.18 \pm 1.31 \mathrm{c}$ & $9.69 \pm 2.85 \mathrm{a}$ & $7.59 \pm 1.17 \mathrm{c}$ & $4.74 \pm 1.07 \mathrm{~b}$ & $37.02 \pm 12.64 \mathrm{~b}$ \\
Dropping & $24.66 \pm 6.62 \mathrm{a}$ & $1.32 \pm 1.02 \mathrm{a}$ & $10.38 \pm 2.57 \mathrm{~b}$ & $6.44 \pm 1.52 \mathrm{a}$ & $4.21 \pm 0.88 \mathrm{a}$ & $28.17 \pm 10.96 \mathrm{a}$ \\
Control & $29.09 \pm 8.98$ & $1.87 \pm 1.02$ & $10.27 \pm 2.62$ & $7.12 \pm 1.25$ & $4.51 \pm 1.07$ & $33.03 \pm 12.17$ \\
Total & & & & & & \\
Weeks & $19.80 \pm 4.69 \mathrm{a}$ & $1.04 \pm 0.38 \mathrm{a}$ & $9.55 \pm 2.15 \mathrm{a}$ & $6.45 \pm 1.14 \mathrm{a}$ & $3.89 \pm 0.94 \mathrm{a}$ & $25.91 \pm 9.52 \mathrm{a}$ \\
1 & $25.71 \pm 5.47 \mathrm{~b}$ & $1.59 \pm 0.59 \mathrm{~b}$ & $11.34 \pm 2.68 \mathrm{c}$ & $7.04 \pm 1.22 \mathrm{~b}$ & $4.46 \pm 1.30 \mathrm{~b}$ & $32.35 \pm 13.48 \mathrm{~b}$ \\
3 & $32.93 \pm 5.63 \mathrm{c}$ & $2.10 \pm 0.08 \mathrm{c}$ & $10.68 \pm 2.76 \mathrm{~b}$ & $7.33 \pm 1.16 \mathrm{c}$ & $4.73 \pm 0.84 \mathrm{c}$ & $35.42 \pm 10.56 \mathrm{c}$ \\
6 & $37.91 \pm 7.04 \mathrm{~d}$ & $2.75 \pm 1.20 \mathrm{~d}$ & $9.52 \pm 2.42 \mathrm{a}$ & $7.60 \pm 1.88 \mathrm{c}$ & $4.96 \pm 0.84 \mathrm{c}$ & $38.44 \pm 11.20 \mathrm{~d}$ \\
9 & $29.09 \pm 8.99$ & $1.87 \pm 1.02$ & $10.27 \pm 2.62$ & $7.12 \pm 1.25$ & $4.51 \pm 1.07$ & $33.03 \pm 12.17$ \\
\hline
\end{tabular}

Note: mean on the same row bearing the same alphabet are not significantly different; ns=not significant.

\subsection{The ANOVA Result of Plant Height, Basal Girth and Leave Production}

The results of analysis of variance of Plant height indicated that treatments $\left(0.01^{* *}\right)$, and week $\left(0.00^{* *}\right)$, significantly influenced height of Eucalyptus torelliana, although, the effect of pot sides $\left(0.91^{\mathrm{ns}}\right)$ was not significant on plant height at $\mathrm{p}<0.05$. The result of 2 way interaction of Pot sizes and treatment $\left(0.44^{\mathrm{ns}}\right)$, pot sizes and weeks $\left(0.76^{\mathrm{ns}}\right)$ were not significant on the plant height but the effect of 2 way interaction of treatments and weeks was highly significant $\left(0.00^{* *}\right)$ on the plant height. The effect of 3 way interactions of Pot sizes, treatments and weeks $\left(0.00^{* *}\right)$ was also highly significant on plant height at $\mathrm{p}<0.05$ with coefficient value of 0.17 (Table 2)

The results of analysis of variance of plant girth indicated that pot size $(0.00 * *)$, and weeks $(0.00 * *)$, significantly influenced the increase in plant girth, the effect of the treatment $\left(0.313^{\mathrm{ns}}\right)$ does not significantly influence plant girth at $p<0.05$. The result of 2 way interaction of treatment and week $\left(0.01^{*}\right)$ was significant on the plant girth and the effect of 2 way interaction of pot size and weeks $\left(0.62^{\mathrm{ns}}\right)$, was not significant on the plant girth. The effect of 3 way interactions of treatments, pot sizes and weeks $\left(0.95^{\text {ns }}\right)$ was also not significant on plant girth at $\mathrm{p}<0.05$ with coefficient value of 0.52 (Table 2 )

The results of analysis of variance of leave production showed that pot size $\left(0.91^{* *}\right)$ was not significant on leave production of Eucalyptus torelliana, the effect of treatment $\left(0.01^{* *}\right)$ and weeks $\left(0.00^{* *}\right)$, significantly influenced leave production at $p<0.05$. The result of 2 way interaction of treatment and pot size $\left(0.44^{* *}\right)$ was not significant on the number of leaves production of the plant. While the effect of 2 way interactions of treatment and weeks $\left(0.00^{* *}\right)$, was as well significant on the leave production. The effect of 2 way interaction between pot sizes and weeks $\left(0.76^{\mathrm{ns}}\right)$, was not significant on the leave production. The effect of 3 way interactions of treatments, pot sizes and weeks $\left(0.00^{* *}\right)$ shows that there was the variables assessed significantly influence leave production at $\mathrm{p}<0.05$ with coefficient value of 0.23 (Table 2).

Table 2. Analysis of variance of parameter assessed (Plant height, Girth and Number of leave).

\begin{tabular}{|c|c|c|c|c|c|c|}
\hline Source & Sum of Squares & Df & Mean Square & $\mathbf{F}$ & Sig & $\mathbf{R}^{2}$ \\
\hline \multicolumn{7}{|l|}{ Plant height } \\
\hline Pot & 0.07 & 1 & 0.075 & 0.013 & $0.91^{\mathrm{ns}}$ & \\
\hline Treatment & 67.09 & 3 & 22.36 & 3.94 & $0.01 *$ & \\
\hline Week & 287.81 & 3 & 95.94 & 16.92 & $0.00 * *$ & \\
\hline Pot $*$ treatment & 15.36 & 3 & 5.12 & 0.90 & $0.44^{\mathrm{ns}}$ & \\
\hline Pot $*$ week & 6.58 & 3 & 2.19 & 0.39 & $0.76^{\mathrm{ns}}$ & \\
\hline Treatment $*$ week & 205.56 & 9 & 22.84 & 4.03 & $0.00 * *$ & \\
\hline Error & 2540.67 & 448 & 5.67 & & & \\
\hline Total & 3286.79 & 479 & & & & 0.17 \\
\hline \multicolumn{7}{|l|}{ Girth } \\
\hline Pot size & 15.23 & 1 & 15.23 & 30.34 & $0.00 * *$ & \\
\hline Week & 192.46 & 3 & 64.15 & 127.79 & $0.00 * *$ & \\
\hline Treatment & 1.79 & 3 & 0.597 & 1.19 & $0.31^{\mathrm{ns}}$ & \\
\hline Treatment $*$ Week & 10.76 & 9 & 1.20 & 2.38 & $0.01 *$ & \\
\hline Treatment $*$ Pot size $*$ Week & 1.66 & 9 & 0.18 & 0.37 & $0.95^{\mathrm{ns}}$ & \\
\hline Error & 224.90 & 448 & 0.50 & & & \\
\hline Total & 502.14 & 479 & & & & 0.521 \\
\hline \multicolumn{7}{|l|}{ Number of leave } \\
\hline Pot size & 0.08 & & 0.08 & 0.01 & $0.91^{\mathrm{ns}}$ & \\
\hline Treatment & 67.09 & 3 & 22.36 & 3.94 & $0.01 *$ & \\
\hline Week & 287.81 & & 95.94 & 16.92 & $0.00 * *$ & \\
\hline treatment $*$ pot size & 15.36 & 3 & 5.12 & 0.90 & $0.44^{\mathrm{ns}}$ & \\
\hline treatment $*$ week & 205.56 & 9 & 22.84 & 4.03 & $0.00 * *$ & \\
\hline pot size $*$ week & 6.58 & 3 & 2.19 & 0.39 & $0.76^{\mathrm{ns}}$ & \\
\hline
\end{tabular}




\begin{tabular}{llllll}
\hline Source & Sum of Squares & Df & Mean Square & F & Sig \\
\hline treatment*pot size*week & 163.66 & 9 & 18.18 & 3.21 & $0.00^{* *}$ \\
Error & 2540.67 & 448 & 5.61 & & \\
Total & 3286.79 & 479 & & & 0.23 \\
\hline
\end{tabular}

Note: $* *=$ highly significant, ${ }^{*}=$ significant $n s=$ not significant (at $5 \%$ probability level)

\subsection{The ANOVA Result of Parameter Assessed (Leave Length, Leave Width and Leave Area)}

The results of analysis of variance of leave length indicated that pot size treatment and weeks $\left(0.00^{* *}\right)$ significantly influenced leave length, while the effect of sapling height $\left(0.00^{* *}\right)$ was also highly significant on the leave length at $\mathrm{p}<$ 0.05 . The effect of 2 way interactions of treatment and pot size $\left(0.00^{* *}\right)$, treatment and week $\left(0.00^{* *}\right)$ was as well significant on the leave length. The effect of 2 way interaction between treatment and week $\left(0.99{ }^{\mathrm{ns}}\right)$, was not significant on the leave length. The effect of 3 way interactions of treatments, pot sizes and weeks $\left(1.00^{\mathrm{ns}}\right)$ shows that there was no significant in leave length at $p<0.05$ with coefficient value of 0.17 with coefficient value of 0.29 (Table 3 ).

The results of analysis of variance of leave width indicated that pot sizes $\left(0.00^{* *}\right)$, and weeks $\left(0.00^{* *}\right)$, significantly influenced leave width of Eucalyptus torelliana, although, the effect of treatments $\left(0.32^{\text {ns }}\right)$ was not significant on leave width at $\mathrm{p}<0.05$. The result of 2 way interaction of Pot sizes and treatment $\left(0.00^{* *}\right)$, was highly significant while that of pot sizes and weeks $(0.95 \mathrm{~ns})$, treatments and weeks $\left(0.86^{* *}\right)$ were not significant on leave width of the plant. The effect of 3 way interactions of Pot sizes, treatments and weeks $\left(0.99^{\text {ns }}\right)$ was not significant on leave width of at $\mathrm{p}<0.05$ with coefficient value of 0.24 (Table 3 )

The results of analysis of variance of leave area indicated that pot sizes $\left(0.48^{\text {ns }}\right)$ did not significantly influenced height of Eucalyptus torelliana while treatments and week $\left(0.00^{* *}\right)$, significantly influenced height at $\mathrm{p}<0.05$. The result of 2 way interaction of treatments and weeks $\left(0.99^{\text {ns }}\right)$, pot sizes and weeks $\left(0.91^{\mathrm{ns}}\right)$ were not significant on leave area but the effect of 2 way interaction of treatments and pot sizes were highly significant $\left(0.00^{* *}\right)$ on the leave area. The effect of 3 way interactions of Pot sizes, treatments and weeks $\left(0.99^{* *}\right)$ was also not significant on leave area at $\mathrm{p}<0.05$ with coefficient value of 0.29 (Table 3 ).

Table 3. Analysis of variance of parameter assessed (Leave length, leave width and leave area).

\begin{tabular}{|c|c|c|c|c|c|c|}
\hline Source & Sum of Squares & Df & Mean Square & $\mathbf{F}$ & Sig & $\mathbf{R}^{2}$ \\
\hline \multicolumn{7}{|l|}{ Leave length } \\
\hline Pot size & 9.89 & 1 & 9.89 & 8.40 & $0.00 * *$ & \\
\hline Treatment & 89.42 & 3 & 29.81 & 25.31 & $0.00 * *$ & \\
\hline Week & 87.30 & 3 & 29.10 & 24.72 & $0.00 * *$ & \\
\hline treatment $*$ pot size & 32.31 & 3 & 10.77 & 9.15 & $0.00 * *$ & \\
\hline treatment $*$ week & 2.15 & 9 & 0.24 & 0.20 & $0.99^{\mathrm{ns}}$ & \\
\hline pot size $*$ week & 0.19 & 3 & 0.06 & 0.05 & $0.98^{\mathrm{ns}}$ & \\
\hline treatment $*$ pot size $*$ week & .217 & 9 & 0.02 & 0.02 & $1.00^{\text {ns }}$ & \\
\hline Error & 527.48 & 448 & 1.18 & & & \\
\hline Total & 748.95 & 479 & & & & 0.29 \\
\hline \multicolumn{7}{|l|}{ Leave width } \\
\hline Pot size & 36.79 & 3 & 12.27 & 13.27 & $0.00^{* *}$ & \\
\hline Treatment & 0.92 & 1 & 0.93 & 0.99 & $0.32^{\mathrm{ns}}$ & \\
\hline Week & 76.36 & 3 & 25.45 & 27.53 & $0.00 * *$ & \\
\hline pot $*$ treatment & 16.16 & 3 & 5.39 & 5.83 & $0.00 * *$ & \\
\hline pot $*$ week & 3.15 & 9 & 0.35 & 0.38 & $0.95^{\text {ns }}$ & \\
\hline treatment $*$ week & 0.69 & 3 & 0.23 & 0.25 & $0.86^{\mathrm{ns}}$ & \\
\hline pot $*$ treatment $*$ week & 1.88 & 9 & 0.21 & 0.20 & $0.99^{\text {ns }}$ & \\
\hline Error & 414.18 & 448 & 0.93 & & & \\
\hline Total & 550.13 & 479 & & & & 0.25 \\
\hline \multicolumn{7}{|l|}{ Leave Area } \\
\hline Treatment & 6622.46 & 3 & 2207.45 & 19.77 & $0.00 * *$ & \\
\hline Pot size & 440.55 & 1 & 440.55 & 3.95 & $0.48^{\mathrm{ns}}$ & \\
\hline Week & 10326.34 & 3 & 3442.11 & 30.83 & $0.00 * *$ & \\
\hline treatment $*$ pot size & 3113.19 & 3 & 1037.73 & 9.29 & $0.00 * *$ & \\
\hline treatment $*$ week & 192.59 & 9 & 21.39 & 1.92 & $0.99^{\mathrm{ns}}$ & \\
\hline pot size $*$ week & 60.40 & 3 & 20.13 & 1.80 & $0.91^{\mathrm{ns}}$ & \\
\hline treatment $*$ pot size * week & 151.26 & 9 & 16.81 & 1.51 & $0.99^{\text {ns }}$ & \\
\hline Error & 50021.37 & 448 & 111.66 & & & \\
\hline Total & 70928.15 & 479 & & & & 0.29 \\
\hline
\end{tabular}

Note: $* *=$ highly significant at $5 \%$ probability level, $*=$ significant at $\mathrm{p}<0.05$, ns $=$ not significant 


\subsection{The Results of Correlation and Regression on Parameter Assessed}

Result of Correlation analysis revealed that there was significant correlation between plant height and Girth ($\left.0.17^{* *}\right)$, plant height and leave width $\left(0.29^{* *}\right)$ and between plant height and leave area $\left(0.72^{* *}\right)$ (Table 4$)$. The result of the regression analysis on the effects of growth variables on tree plant height had coefficient of $\left(\mathrm{R}^{2}=.089\right)$ (Table 5) meaning that the assessed growth variables had about $89.0 \%$ effects on plant height of Eucalyptus torelliana tree under intense nursery management.

Table 4. Correlations analysis of parameters assessed.

\begin{tabular}{|c|c|c|c|c|c|c|c|c|}
\hline & & Pot size & Girth & Leave Num & Leave length & leave width & leave Area & $\begin{array}{l}\text { plant } \\
\text { height }\end{array}$ \\
\hline \multirow{3}{*}{ Pot size } & Pearson Correlation & 1 & & & & & & \\
\hline & Sig. (2-tailed) & & & & & & & \\
\hline & $\mathrm{N}$ & 480 & & & & & & \\
\hline \multirow{3}{*}{ Girth } & Pearson Correlation & $-0.17^{* *}$ & 1 & & & & & \\
\hline & Sig. (2-tailed) & 0.00 & & & & & & \\
\hline & $\mathrm{N}$ & 480 & 480 & & & & & \\
\hline \multirow[t]{2}{*}{ Leave Num } & Sig. (2-tailed) & 0.92 & 0.74 & & & & & \\
\hline & $\mathrm{N}$ & 480 & 480 & 480 & & & & \\
\hline \multirow{3}{*}{ Leave length } & Pearson Correlation & $-0.12^{*}$ & $.466^{* *}$ & 0.02 & 1 & & & \\
\hline & Sig. (2-tailed) & 0.01 & 0.00 & 0.66 & & & & \\
\hline & $\mathrm{N}$ & 480 & 480 & 480 & 480 & & & \\
\hline \multirow{3}{*}{ Leave width } & Pearson Correlation & -0.04 & $0.39^{* *}$ & 0.03 & $0.72^{* *}$ & 1 & & \\
\hline & Sig. (2-tailed) & 0.37 & 0.00 & 0.46 & 0.00 & & & \\
\hline & $\mathrm{N}$ & 480 & 480 & 480 & 480 & 480 & & \\
\hline \multirow[t]{2}{*}{ Leave Area } & Sig. (2-tailed) & 0.09 & 0.00 & 0.58 & 0.00 & 0.00 & & \\
\hline & $\mathrm{N}$ & 480 & 480 & 480 & 480 & 480 & 480 & \\
\hline \multirow{3}{*}{ Plant height } & Pearson Correlation & -0.07 & $0.71^{* *}$ & $0.09^{*}$ & $0.47^{* *}$ & $0.44^{* *}$ & $0.49^{* *}$ & 1 \\
\hline & Sig. (2-tailed) & 0.06 & 0.00 & 0.04 & 0.00 & 0.00 & 0.00 & \\
\hline & $\mathrm{N}$ & 480 & 480 & 480 & 480 & 480 & 480 & 480 \\
\hline
\end{tabular}

$* *=$ correlation is significant at $1 \%$ level $\mathrm{p}<0.01, *=$ correlation is significant at $5 \%$ level $\mathrm{p}<0.05$

Table 5. Table of Regression Parameters.

\begin{tabular}{|c|c|c|c|c|c|c|c|}
\hline \multirow{2}{*}{\multicolumn{2}{|c|}{ Model }} & \multicolumn{2}{|c|}{ Unstandardized Coefficients } & \multirow{2}{*}{$\begin{array}{l}\text { Standardized Coefficients } \\
\text { Beta }\end{array}$} & \multirow{2}{*}{$\mathbf{T}$} & \multirow{2}{*}{ Sig. } & \multirow{2}{*}{$\mathbf{R 2}$} \\
\hline & & B & Std. Error & & & & \\
\hline \multirow{7}{*}{1} & (Constant) & 5.89 & 2.37 & & 2.488 & $0.01 *$ & \\
\hline & Pot & 0.22 & 0.23 & 0.04 & 0.94 & $0.35^{\mathrm{ns}}$ & \\
\hline & Treatment & 0.48 & 0.11 & 0.20 & 4.219 & $0.00 * *$ & \\
\hline & Week & -0.34 & 0.06 & -0.40 & -5.63 & $0.00 * *$ & \\
\hline & Leave Num & 0.13 & 0.02 & .430 & 5.71 & $0.00 * *$ & \\
\hline & Leave Length & 0.06 & 0.34 & 0.03 & 0.17 & $0.86^{\mathrm{ns}}$ & \\
\hline & Leave Area & -0.02 & 0.08 & -0.09 & -0.24 & $0.81^{\mathrm{ns}}$ & 0.89 \\
\hline
\end{tabular}

a. Dependent Variable: Plant Height

Note: $* *=$ correlation is significant at $1 \%$ level $\mathrm{p}<0.01, *=$ correlation is significant at $5 \%$ level $\mathrm{p}<0.05$, ns $=$ not significant, Dependent variable: $\%$ height increment, S. E. E mean standard Error Estimate

\section{Discussion}

The study considered the effect of pot sizes (big and small) and organic manure (Cow dung and poultry droppings) on the growth of Eucalyptus torelliana F. Muell. at seedlings growth stage at the nursery. The study was carried out with the aim to evaluate the early growth and development response of Eucalyptus torelliana F. Muell. raised in different pot sizes to organic fertilizer treatment at the nursery site of the Department of Forestry and Wildlife Management, Faculty of Agriculture Nasarawa State University Lafia campus.
Effect of early growth assessment of Eucalyptus torelliana F. Muell. treated with two different pot sizes $(16$ by $10 \mathrm{~cm}$ for big size and 12 by $8 \mathrm{~cm}$ for small size), the result in all respect showed that the best soil media for Eucalyptus torelliana F. Muell. is the big pot size. This result corroborates Geply et al. in a study carried out effect of different pot sizes and growth media on the agronomic performance of Jatropha curcas. He reported that when Jatropha in a big pot performed better in terms of height than when it was in a small pot [11]. This also agrees with the findings of Hopkins and White who reported that large polythene pot had higher level of significance on the early growth Pakia biglobosa compared to small polythene pot 
[12], Oni and Caspa also reported that large polythene pot had an effect on seedlings growth compared with small polythene pot in term of stem girth [13]. This could be due to the ability of large polythene pot containing large amount of soil nutrient and water molecules.

The report of growth parameter also revealed the application of organic manure significantly affect the growth rate of Eucalyptus torelliana F. Muell. this therefore shows that Plant growth is directly related to the availability of nutrient in the soil as the Eucalyptus torelliana F. Muell. plant in treated soil sample performed better than the those in the untreated soil. The application of manure had a positive effect on the growth of the assessed variable such as plant height, basal girth and number of leaves produced and other leave parameters including leave area. The result showed that the sapling of Eucalyptus torelliana F. Muell. treated with poultry droppings recorded the highest mean value of the growth in most of the accessed parameters including plant height and Plant girth. This could be attributed to the fact that nutrient availability in the soil enriches and improves plant growth. This is in accordance with the study of Egbewole where he assessed the early growth of Araucaria heterophylla seedlings, where he recorded highest mean value in soil treated with poultry droppings [14]. It is recorded that plant cow dung treatment also improve Eucalyptus torelliana F. Muell. growth with mean values higher than the control treatment and $76.09 \pm 1.9 \mathrm{~cm}$ as the least plant height value recorded for control. This is in-line with the study of Rotowa et al in a study they carried out to evaluate the growth response of Moringa olifera to organic and mineral fertilizer treatment where poultry manure recorded the highest yield of growth parameter assessed as followed by cow dung treatment [15].

This implies that both treatment (growth and germination media and poly pots) used for nursery propagation of Eucalyptus torelliana under the same geographical and weather conditions have significant influence on the agronomic parameters determined. Different pot sizes and growth media influenced the nursery performance of Eucalyptus torelliana F. Muell. after assessed for the period of nine weeks. This study shows that both the growth media and poly pots improved the nursery performance of Eucalyptus torelliana F. Muell., this is similar with the findings of Igboanugo, which showed that when Triplochiton scleroxylon seedlings were transferred to a more pleasant environmental conditions, there was an upsurge in their shoot growth and growth of other morphological parameters than were possible in their previous environments [16] and the study of Geply et al. who reported better growth significant influence on the agronomic parameters determined on Jatropha curcas [11]. The result also agrees with the findings of on Eucalyptus clones which recorded significantly higher height increment and higher GBH increment where lowest height increment was recorded in the control [17].

The correlation analysis showed that there was positive significant relation between sampling height and weeks, this indicated that as week increases likewise the sampling height, basal girth, branches and possibly leave number also increase, this is growth trend is in accordance with the result of previous researches $[11,14,15,18,19]$. The result of correlation further showed that there was a significant variation on the growth of Eucalyptus torelliana seedlings based on the treatment given and weeks of assessment. There is also a positive significant relationship between plant height which is the major growth factor and other growth parameters including plant girth, number of leaves and leave area. While the result of regression analysis on the effect of growth variable on sample height had coefficient of determination $\left(\mathrm{R}^{2}=0.89\right)$ meaning that the assessed growth variable had about $89 \%$ effects on the sampling height of Araucaria heterophylla.

\section{Conclusion and Recommendations}

The types of organic manure and the size of polythene pot for risen successful seedlings in nursery is very essential to choose. On the basis of result obtained from this study, it is concluded that potting media (polythene pot) and organic manure significantly influenced the germination, growth and development of Eucalyptus torelliana seedlings. The overall result revealed that poultry dropping mixed with top soil filled in polythene pot size of 16 by $10 \mathrm{~cm}$ has highest growth and development compared to that of polythene pot size 12 by $8 \mathrm{~cm}$ and cow dung, poultry droppings + Cow dung and control (top soil). From the result of the study, it is recommended that poultry droppings treatment and large polythene pot sizes performed better than the other treatments. Therefore, it should be adopted in raising Eucalyptus torelliana in the nursery. However, further research activities on the organic manure and pot sizes on raising Eucalyptus torelliana should be done to ascertain the result of this work. This will go a long way to boost the production of Eucalyptus torelliana trees and its sustainability for wood based industries.

\section{References}

[1] Adeniyi B. A. and Ayepola O. O. (2008). The Phytochemical Screening and Antimicrobial Activity of Leaf Extracts of Eucalyptus camaldulensis and Eucalyptus torelliana (Myrtaceae). Research Journal of Medicinal Plants, 2: 34-38.

[2] Adeniyi A. G., Odufowoke R. O. and Olaleye S. B. (2006). Antimicrobial and Gastroprotective properties of Eucalyptus torelliana (Myrtaceae) Crude extracts. Intl J. Pharmac, 2: 362-365

[3] Coffi K., Soleymane K., Harisolo R., Balo T., Claude C. J., Pierre C., Gilles F. and Antoine A. (2012). Monoterpene Hydrocarbons, Major Components of the Dried Leaves Essential Oils of Five Species of the Genus Eucalyptus from Côted'Ivoire. J. Natural Science, 4 (2): 2012, 106-111.

[4] Pinto G., Correia S., Corredoira E., Ballester A., Correia B., Neves L. and Canhoto J. (2016). In Vitro Culture of Eucalyptus: where do we stand? In Park Y., Bonga J. M. and Moon H. (Eds.), Vegetative Propagation of Forest Trees. (National Institute of Forest Science (NIFOS) Seoul, Korea. 507-532. 
[5] Rockwood D. L., Rudie A. W., Ralph S. A., Zhu J. Y. and Winandy J. E. (2008). Energy Product Options for Eucalyptus Species Grown as Short Rotation Woody Crops. Int J Mol Sci. 9 (8): 1361-1378.

[6] Ololade Z. S and Olawore N. O. (2013). Chemistry and Medicinal Potentials of the Seed Essential Oil of Eucalyptus torelliana F. Muell Grown in Nigeria Global. Journal of Science Frontier Research Chemistry, 13 (3): 2013, 1-11.

[7] Alian A. G., Felician A., Boniface Y., Alian K. Y., Chantal M. and Dominique S. (2012) Chemical and Biological Investigation of Leaves of Eucalyptus torelliana Essential Oil from Benin. International Research Journal of Biological Science, 1 (5): 6-12.

[8] Chalchat J. C., Gary R. P., Sidibe L. and Harama M. Aromatic Plant of Mali (v): (2000). Chemical composition of four Eucalyptus species implanted in Mali. E. Camaldulensis, E. torelliana, E. citriodora, E. tereticornis. J of Ess Oil Res, 12: 695-701.

[9] Farah A., Fechtal M., Chouch A. and Zarira S. (2002). The Essential Oil of Eucalyptus camaldulensis and its Natural Hybrid (clone 583) from Morocco. Flav Fragr J, 17: 395-397.

[10] Jayeoba, O. J (2013). Land suitability elevation for arable agriculture in Nasarawa state using Geoinformation. A Ph. D thesis department of geography, Nasarawa State University Keffi. Pp. 247

[11] Geply, O. A., Baiyewu, R. A., Adegoke, I. A,. Ayodele O. O and. Ademola I. T: (2011): Effect of Different Pot Sizes and Growth Media on the Agronomic Performance of Jatropha curcas. Pakistan Journal of Nutrition 10 (10): 952-954, 2011 ISSN 1680-5194

[12] Hopkins, H. C. and F. White, 1984. The ecology and chiology of Pakia in Africa. Bull, Jard. Bot. Wat. Belg., 84: 253-266.
[13] Oni, O. and R. G. Caspa, 2002. Effect of soil sources and pot sizes on the early growth of an indigenous multipurpose tree species (Pakia biglobosa). J. Ecol., 4: 50-58.

[14] Egbewole, Z. T. (2017). Assessment of Early Growth and Profitability of Sales of Araucaria heterophylla Seedlings inSelected Locations in the Middle Belt Zone of Nigeria. International Journal of Applied Research and Technology. 6 (8): $116-125$.

[15] Rotowa, O. J., Ugonma, D. A., Egbewole, Z. T. and Bhadmus, H. B. (2017). Growth Response of Moringa oleifera Lam to Organic and Mineral Fertilizers Treatment. International Journal of Applied Research and Technology. 6 (5): 51 - 56.

[16] Igboanugo, A. B., 1990. Adaptations of shoot growth and leaf production of laboratory-grown cuttings of Triplochiton scleroxylon K. Schum in response to changes in irradiance. Forest Ecol. Manage., 1-2: 135-142.

[17] Anubha Srivastav, Anita Toma, Alok Yadav, S. D. Shukla and Yogesh Agrawal (2018) Early Performance of Eucalyptus Clones in Vindhyan Region of Uttar Pradesh, India. Srivastav Anubha et. al; International Journal of Advance Research, Ideas and Innovations in Technology. Volume 4, Issue 2) Available online at: www.ijariit.com

[18] Hartmann, H. T., Kester, D. E., Davies, F. T. and Geneve, R. L. (2002). Plant Propagation - principles and practices. $7^{\text {th }}$ Edition. Prentice Hall.

[19] Rotowa O. J. and Adeagbo A. A (2019) Provenance trial of Gmelina aborea (Roxb.) in middle-Belt Zone of Nigeria. Research Journal of Agriculture and Forestry Vol. 7 (3), $27-$ 31, July (2019) 56. 